OPEN ACCESS

Edited by:

Daniel Palacios-Marqués, Universitat Politècnica de València,

Spain

Reviewed by:

Fernanda Alberto,

Instituto Politécnico de Coimbra,

Portugal

Giovanni Herrera,

University of the Armed Forces

(ESPE), Ecuador

*Correspondence:

Vera Gelashvill

vera.gelashvili@urjc.es

Specialty section:

This article was submitted to

Organizational Psychology,

a section of the journal

Frontiers in Psychology

Received: 30 July 2021

Accepted: 27 August 2021

Published: 16 September 2021

Citation:

Martínez-Navalón J-G,

Gelashvili V and Gómez-Ortega A (2021) Evaluation of User Satisfaction

and Trust of Review Platforms:

Analysis of the Impact of Privacy and $E-W O M$ in the Case

of TripAdvisor.

Front. Psychol. 12:750527. doi: 10.3389/fpsyg.2021.750527

\section{Evaluation of User Satisfaction and Trust of Review Platforms: Analysis of the Impact of Privacy and E-WOM in the Case of TripAdvisor}

\author{
Juan-Gabriel Martínez-Navalón, Vera Gelashvili* and Alba Gómez-Ortega \\ Department of Business Economic, Faculty of Legal and Social Sciences, King Juan Carlos University, Madrid, Spain
}

Technological advances have had many advantages like an E-WOM (Electronic Word of Mouth) that has become a very important and powerful tool for users who wish to share their knowledge, experiences and emotions about a product or service. But the use of virtual platforms may affect the privacy of users data. This present study has a twofold objective: first check if the privacy of users when using TripAdvisor, the world's largest travel platform, has an impact on their satisfaction and trust on the platform. Secondly, the relationship between E-WOM and the variables users trust and satisfaction when using TripAdvisor is examined. In order to achieve the objectives set out, the sample of 390 persons was analyzed. The PLS-SEM method has been used to process the data and test the hypotheses. The results of the analysis have shown that there is a positive and direct relationship between TripAdvisor users' privacy and satisfaction. The direct and positive relationship between users' E-WOM and their degree of satisfaction and trust toward the platform has also been confirmed. This study makes a significant contribution to the academic literature on the variables studied, as previous studies presented different results.

Keywords: privacy, satisfaction, trust, E-WOM, TripAdvisor

\section{INTRODUCTION}

Technological development and its application in social networks have had a significant impact on the way in which consumers exchange their experiences and opinions. Authors such as Bigné et al. (2013) note the influence that the exchange of online experiences has on the attitude toward the brand and the brand's influence on purchase intention. According to Alonso (2016), digital tools create groups of belonging that condition behavior, as they create widely accepted trends of opinion. Consumers are the main promoters of brands, due to the frequency in the use of social networks, they have the power to promote or discredit a company in a matter of seconds, even at an international level (Apolo et al., 2015). This is why companies should take into account digital marketing strategies (Saura, 2020).

According to Sánchez and Arroyo-Cañada (2016), there are important differences between the traditional shopping process and online shopping. One of them is the degree of technological 
interaction (Agudo-Peregrina et al., 2014). The use of digital platforms for reviews and opinions is one of the most important tools in terms of consumer interaction. The emergence of these platforms has significantly reduced transaction costs, which explains the enormous prominence they have acquired in recent years (Belleflamme and Peitz, 2018). These authors argue that reviews and feedback are an almost consubstantial element of digital platforms. During the purchasing process, consumers seek evaluations and recommendations about the attributes of a product or service, and to do so, they use various sources of information, including these platforms (Pérez-Aranda et al., 2017). As these authors point out, the final purchase decision of users is closely linked to E-WOM, so it is necessary to analyze how organizations, and especially hotels, manage the evaluations shared on line by users. Gil et al. (2017) state that the tourism sector, and specifically the hotel sector, is particularly vulnerable to the opinions generated by travelers (Buhalis and Law, 2008) and is clearly affected online by the so-called E-WOM.

On the other hand, the technological development and exponential growth of digital platforms, mentioned above, makes it essential to analyze user privacy and its impact on the management of these tools. This problem, applied to social networks, is highly debated (Kayes and Iamnitchi, 2017). However, we cannot forget the importance that privacy can have for a platform where users can express their opinion about a service received. Understanding that the opinion may be conditioned by the continuity of the service in the future and by the relationship with the company that offers it. For this reason privacy management of user information is becoming increasingly complex (Trepte, 2020).

Given the above, this study has a twofold objective. On the one hand, to analyze how privacy affects user satisfaction and trust, when using review platforms. On the other hand, whether E-WOM has an impact on these variables. To carry out the study, TripAdvisor has been selected as one of the most important digital platforms (Balagué et al., 2016; Yoo et al., 2016; Gil et al., 2017; Mariottini and Toribio, 2017).

The data were collected through an online questionnaire that collected users' opinions about TripAdvisor. After the current introduction, the theoretical framework is developed, setting the studied variables: privacy, E-WOM, satisfaction and trust. Subsequently, the 5 hypotheses to be tested are presented and justified, followed by an explanation of the research model. Next, the analysis of the data collected will be presented, ending with a discussion of the results and the main conclusions of the study.

The main results show that there is a positive and direct relationship between TripAdvisor users' privacy and satisfaction. Meanwhile, the hypothesis that analyzed the relationship between TripAdvisor users' privacy and trust has been rejected. The direct and positive relationship between users' E-WOM and their degree of satisfaction and trust toward the platform has also been confirmed.

The interest of this paper lies in finding managerial implications for Tripadvisor's future strategies. In the literature review, no previous studies have been found that analyze privacy and E-WOM hand in hand, in order to know their impact on user satisfaction and trust.

\section{THEORETICAL FRAMEWORK}

\section{Privacy}

Technological evolution has changed life for all people, achieving greater efficiency, products and services that were not previously available to users, thereby improving conditions and the quality of life in general (Funk et al., 2018; Chen et al., 2021). People use electronic tools on a daily basis, which in turn provide different Applications (hereafter Apps) that make it possible to access various services and products simply by registering (Sturm et al., 2018; Tao and Edmunds, 2018). For example, using Apps to move around the city (Uber, Cabify, car sharing Apps) records information about where a person moves, shopping Apps (supermarkets, clothes shops, make-up shops, etc.) store information about a person's tastes and preferences, or simply searching for a term in a search engine stores the searched information. On the basis of these searches and purchases a database is created for a specific person and all adds or offers then take into account the previously collected information (Goldenberg et al., 2012; Fainmesser et al., 2019). Because of this, companies have the possibility to design specific offers for their customers (Gelashvili et al., 2021), but the big question is whether this affects or not user's privacy and security on digital platforms (Saura et al., 2021a,b) since, actually more and more personal information is being processed, shared or disseminated by companies (Ribeiro-Navarrete et al., 2021).

Therefore, one of the drawbacks of this technological advance is a lack of privacy, in particular digital privacy (Munuera, 2017). Privacy is understood as a matter of controlling one's own data, including information disclosure (Sarikakis and Winter, 2017). Study elaborated by Sarathy and Robertson (2003) indicates that individualized information based on users' activities on online platforms allows companies to offer personalized marketing, but this may cause an alarm about the private data of individuals.

The problem of data privacy is particularly visible in social networks (Kayes and Iamnitchi, 2017). Increasingly, users face a lack of control over their information on social networks as they cannot control what companies or other users do with the information they share online. This is why the control of individual users' information has become more difficult (Trepte, 2020). As stated by Beigi and Liu (2018), the daily use of social networks by users has generated an enormous amount of usergenerated data that is used by researchers and service providers being an opportunity for them, but that in turn creates a risk of exposing individuals' privacy. According to Fainmesser et al. (2019) in recent years, there has been growing concern about the privacy and security of users' data, for this reason governments have designed and implemented new laws and regulations that do not provide $100 \%$ protection but are partially effective at best.

\section{E-WOM}

Nowadays, the accessibility of online platforms has enabled users to change their opinions about products and services. On the basis of these opinions, many customers decide whether or not to consume a service and purchase a product (Jiménez-Castillo and Sánchez-Fernández, 2019; Nuseir, 2019). 
This method of exchange or expression of consumer-generated opinions on the Internet is called E-WOM. Usually these opinions are addressed to other users. One of the first definitions of E-WOM (Hennig-Thurau et al., 2004) states that E-WOM is any positive or negative statement made by potential, actual or former customers about a product or company, which is made available to a multitude of people and institutions via the Internet. E-WOM has a major impact on both businesses and their consumers (López and Sicilia, 2014). Through social networks and electronic channels consumers can express their opinion which is visible to the rest of the users, if these comments are negative other consumers will avoid buying or acquiring those products and services which will generate a decrease in sales for the companies (Sa'ait et al., 2016; Li et al., 2019). In addition to this, if companies will not take into account the importance of E-WOM for businesses, there will be a high probability with customer satisfaction, loyalty and trust (Rialti et al., 2017; Duarte et al., 2018; Mishra and Singh, 2019; Tran and Strutton, 2020).

According to Reyes-Menendez et al. (2019) there are different social network sites or platforms like Facebook, Instagram, Twitter, Amazon, Expedia or TripAdvisor that can be useful to inform about the features or benefits of products and services. With a special focus on TripAdvisor, it can be considered as one of the most important E-WOM platforms in the tourism sector. The comments and opinions generated by users generate trust in other users, for this reason it is necessary to manage correctly the content on platforms since there may be some false opinions that can affect the reputation of companies.

But E-WOM is not only in the tourism sector that has an importance. Study elaborated in the banking sector have shown that E-WOM is positively related to loyalty, trust and purchase intention (Guping et al., 2021; Zhang et al., 2021). Another study elaborated by Tjhin and Aini (2019), has found that E-WOM has a significant effect on purchase decision and consumer trust in clothing industry. This means that in almost all industries E-WOM has an important significance. For this companies need to be aware of the huge impact E-WOM has on consumers and to avoid problems they need to pay special attention to customer satisfaction and complaints (López and Sicilia, 2014).

\section{Satisfaction}

Nowadays user satisfaction plays an important role for the performance and growth of the companies (Eklof et al., 2020; Otto et al., 2020). User satisfaction is defined as the users' opinion of the service or products received compared to the service or products expected (Jani and Han, 2011). This means that if the customer has expectations of receiving a product or service of a certain quality and when they receive these products and services in line with expectations, satisfaction is generated. Therefore, through customer satisfaction companies can know the tastes and preferences of their customers (Alsini, 2017).

Through satisfaction it is possible to study the trust and loyalty generated by users toward the company or products. According to Gelashvili et al. (2021) when using mobile Apps for restaurant reservation has a positive and direct impact on users' trust in restaurants. Likewise, researches carried out on tourism companies have shown that when the user of these companies is satisfied with the services, trust is generated (Lai, 2014; Martínez-Navalón et al., 2019). In addition to trust, another variable that has been studied along with satisfaction by several studies is loyalty (El-Adly, 2019; Thamrin et al., 2020). These studies have shown that user satisfaction is positively related to user loyalty toward the brand. In other words, if satisfaction is generated toward a product or service, this positively affects the loyalty of customers, who will continue to buy the same products and services. Therefore, we can say that these two variables are important for companies to be taken into account. Apart from these two variables, the direct and positive relationship of customer satisfaction with the variables like continuance intention or service quality among others has been studied (Chumpitaz and Paparoidamis, 2007; Liang et al., 2018; Hossain et al., 2019).

In short, user satisfaction is a key factor for companies, because a satisfied customer is a customer who intends to repurchase, trusts the brand and is loyal to the company's products and services. This implies a long term relationship between the customer and the company.

\section{Trust}

The variable trust is one of the most important variables in analyzing customer behavior and has been the subject of research over the decades (Swan et al., 1985; Komiak and Benbasat, 2004; Leninkumar, 2017; Al-Khalaf and Choe, 2020). According to McKnight and Chervany (2001) it is not easy to define the term trust, as most definitions are confusing and for this reason some researchers have chosen not to go further in defining the concept. This may be because each discipline defines and analyses trust from its own perspective. In social sciences customer trust is referred to as the willingness of the consumer to rely on a service brand because he or she has confidence in the reliability and integrity of that brand (Zhang and Bloemer, 2008). In other words, trust could be defined as the users' confidence or faith in the brand's products and services. According to MartínezNavalón et al. (2019) a customer who has trust in the brand's products and services could help the company improve its profitability and achieve other business goals. Another advantage for companies is that the trust variable creates a stable and collaborative user-company relationship (Bilgihan and Bujisic, 2015). As we can see, it is essential for companies to create the trust of their users toward their products and services, which will help to improve their economic and financial situation as well as competitiveness in the market.

Study carried out by Aurifeille et al. (2009), on the measurement of trust indicates that it is not easy to measure thisvariable since there are several studies that analyze customer trust based on various dimensions, among them it can be seen the following dimensions: reliability, credibility, honesty, benevolence, expectation or confidence among others. Lassala et al. (2010) to measure customer trust, uses the following three dimensions: competence, benevolence and honesty, where honesty is defined as the belief that the other party will fulfill 
the promises and obligations undertaken. Competence refers to the professionalization of companies in terms of promised quality, know-how and ability to do their job well. And finally, the dimension of benevolence refers to the belief that the other party is interested in achieving joint benefits and will make decisions that will be beneficial to both parties. Several recent studies (Martínez-Navalón et al., 2019; Gelashvili et al., 2021) have supported the use of these three dimensions to measure customer trust toward a company's products or services.

\section{HYPOTHESES AND RESEARCH MODEL}

One of the industries where E-WOM is most important is the tourism sector (Nieto-García et al., 2017; Kanje et al., 2020). As usual, people before making a trip always look at the content generated on websites about different tourist destinations, quality of hotels or the hospitality industry in general. In case of a set of negative or unfavorable comments on sites such as TripAdvisor, Google Maps, Airbnb or Booking among others may be detrimental to future customers. All these Apps allow consumers to express their opinion about a service or product in the tourism sector (Wu et al., 2013; Reyes-Menendez et al., 2019; Boukherouk et al., 2020). But undoubtedly the most used by consumers or future consumers is TripAdvisor (Valdivia et al., 2017; Reyes-Menendez et al., 2019).

TripAdvisor was founded in the United States in 2000 and is currently the most popular platform in the tourism sector where users can find reviews and information about tourist destinations, restaurants and other tourist attractions (Miguéns et al., 2008; O'connor, 2008; Valdivia et al., 2017). That's means that the users can find the information they need to make their travel decisions based on other users review. The popularity and evolution of this platform is directly related to E-WOM as the relationship between users is through the internet and opinions (Fili and Križaj, 2017; Reyes-Menendez et al., 2019). But to post a review on TripAdvisor to generate E-WOM content about a tourist destination, restaurant or tourist experience requires registration, which is related to the provision of personal data that may affect users' privacy.

Privacy for the user of a service, in the digital framework, is an issue of transcendental relevance and there are numerous recent research studies that analyze this variable and its impact on the user (Chung et al., 2021; Lax et al., 2021; Pilton et al., 2021; Saura et al., 2021c; Wu et al., 2021). This has led competent authorities to develop specific regulations that allow users to manage their privacy preferences when they log on to a platform (Tamburri, 2020; Curry, 2021). Within the European Union (European Commission, 2016), the General Data Protection Regulation 2016/679 was developed in 2018 (hereafter, GDPR). According to Politou et al. (2018), the GDPR encompasses some new data protection principles for giving control back to individuals over their personal data such as the right to object to profiling, the right to data portability, and the obligation for data protection impact assessments. This raises the question of whether or not user privacy can have an impact on the satisfaction of a service received. Some authors have shown that privacy risk leads to a reduction in user satisfaction (Cheng and Jiang, 2020). However, Kim et al. (2012) in their work claim that there is no such relationship. Therefore, taking into account the importance of privacy as a variable and the difference in the results of the aforementioned research, the first hypothesis to be tested is the following:

$\mathbf{H}_{1}$ The privacy of users when using TripAdvisor has a direct and positive impact on their satisfaction on the platform.

Other authors have also linked privacy to user trust. Mutimukwe et al. (2020), claim that perceptions of privacy risk influence user trust and behavior. Aïmeur et al. (2016), conduct an experimental study to compare user trust under two different privacy policies. These authors conclude that changing the appearance of privacy policies makes online services appear more trustworthy to the user. For its part, Voloch et al. (2021), propose a model where user privacy policy is conditioned by three significant aspects, trust, role-based access control and information flow. Due to the relationship shown in different studies between privacy and trust, the second hypothesis to be analyzed is the following:

$\mathbf{H}_{2}$ The privacy of users when using TripAdvisor has a direct and positive impact on their trust on the platform.

Emotions and sensations determine consumer behavior in many cases. According to Heyes and Kapur (2012), the growth of E-WOM affects quality choices. A customer experiencing poor quality may decide to change supplier. The E-WOM phenomenon and its impact on consumer decisions has been analyzed on numerous occasions (Goyette et al., 2012; López and Sicilia, 2014; Yoo et al., 2016; Krishna and Kim, 2020). However, the existence of so-called "bots" can lead to some manipulation of the opinion of a service (Cheng et al., 2020). These bots consist of automated processes that generate mass reviews, positive or negative, created for a specific purpose (Orabi et al., 2020). All of the above makes it essential to understand how the processes of opinion transmission between consumers are generated and the extent to which they affect consumer decisions (Wang et al., 2018; Ismagilova et al., 2019). In this sense, there are different studies that relate E-WOM to user satisfaction (Aakash and Aggarwal, 2019; Serra-Cantallops et al., 2020; Tandon et al., 2020). The analysis of this relationship in the specific field of review platforms leads to the third hypothesis:

$\mathbf{H}_{3}$ The E-WOM on TripAdvisor has a direct and positive impact on the satisfaction of users of the platform.

As a continuation of the previous hypothesis, studies have also been identified that relate E-WOM to the trust generated in the user (Ladhari and Michaud, 2015; Reimer and Benkenstein, 2016; Bhandari and Rodgers, 2017). Therefore, we propose the fourth hypothesis to be tested in this study:

$\mathbf{H}_{4}$ The E-WOM on TripAdvisor has a direct and positive impact on the trust of users of the platform. 
Numerous studies have analyzed the relationship between user satisfaction and user trust in different application areas. Some authors have identified a direct relationship between the two and the quality of service (Dwyer et al., 1987; Crosby et al., 1990; Shamdasani and Balakrishnan, 2000; HenningThurau et al., 2001; Chumpitaz and Paparoidamis, 2007). Other authors consider that both variables have a significant impact on consumer loyalty (Hossain et al., 2019; Thamrin et al., 2020). More recent studies such as Martínez-Navalón et al. (2019), show how in tourism companies, user satisfaction on social networks influences trust in these companies. Lai (2014) demonstrated the relationship between satisfaction with a travel agency and improved trust in the travel agency. Another study elaborated by Liang et al. (2018), explores the relationship between satisfaction, trust and repurchase intention. Gelashvili et al. (2021) demonstrated that the satisfaction of users who make restaurant reservations via a mobile Apps has a direct impact on trust in those restaurants. Based on the above, we consider it interesting to formulate the following hypothesis, to study the relationship between satisfaction and trust as applied to a travel service review and rating platform:

$\mathbf{H}_{5}$ The satisfaction of users when using TripAdvisor has a direct and positive impact on their trust on the platform.

Taking into account all of the hypotheses set out above, the following research model is proposed (Figure 1):

In consideration of the review of the literature on the study's main variables, it is expected that all hypotheses will be accepted.

\section{DATA ANALYSIS}

\section{Data Collection}

The objective of this study was to study users who use the TripAdvisor website with the aim of finding managerial implications for the company's future strategy approach. Therefore, it analyses how privacy and E-WOM affect the satisfaction and trust of users of this review website in tourism and hospitality.

In order to carry out this study, an online questionnaire data source was used. This questionnaire has had a selfadministered format that has collected the opinion of users of this Apps living in central Spain. Specifically in the regions of Castilla-La Mancha and Madrid. Focusing on localities such as Albacete, Chinchilla de Montearagón, Guadalajara, Cuenca, Madrid, Chinchón, Arroyomolinos, Móstoles, Fuenlabrada, etc. This sample is motivated by the intention of finding out the opinion of the population in the interior of Spain. Data collection took place during the months of May and June 2021. In order to have a greater veracity of the data, the IP of the users was checked, avoiding that the same user fills in the form twice.

The data collection process was divided into two stages. In the first stage, a sample of 50 questionnaires was collected in order to carry out a pre-test. Once it was verified that the measurement scale was well done, the second part was developed, which was the collection of the majority of data, where 400 questionnaires were obtained. Of these sample, 390 were valid.

The questionnaire used in this study was divided into two parts. In the first part, questions were asked to classify the users. For this classification, questions were asked about gender,

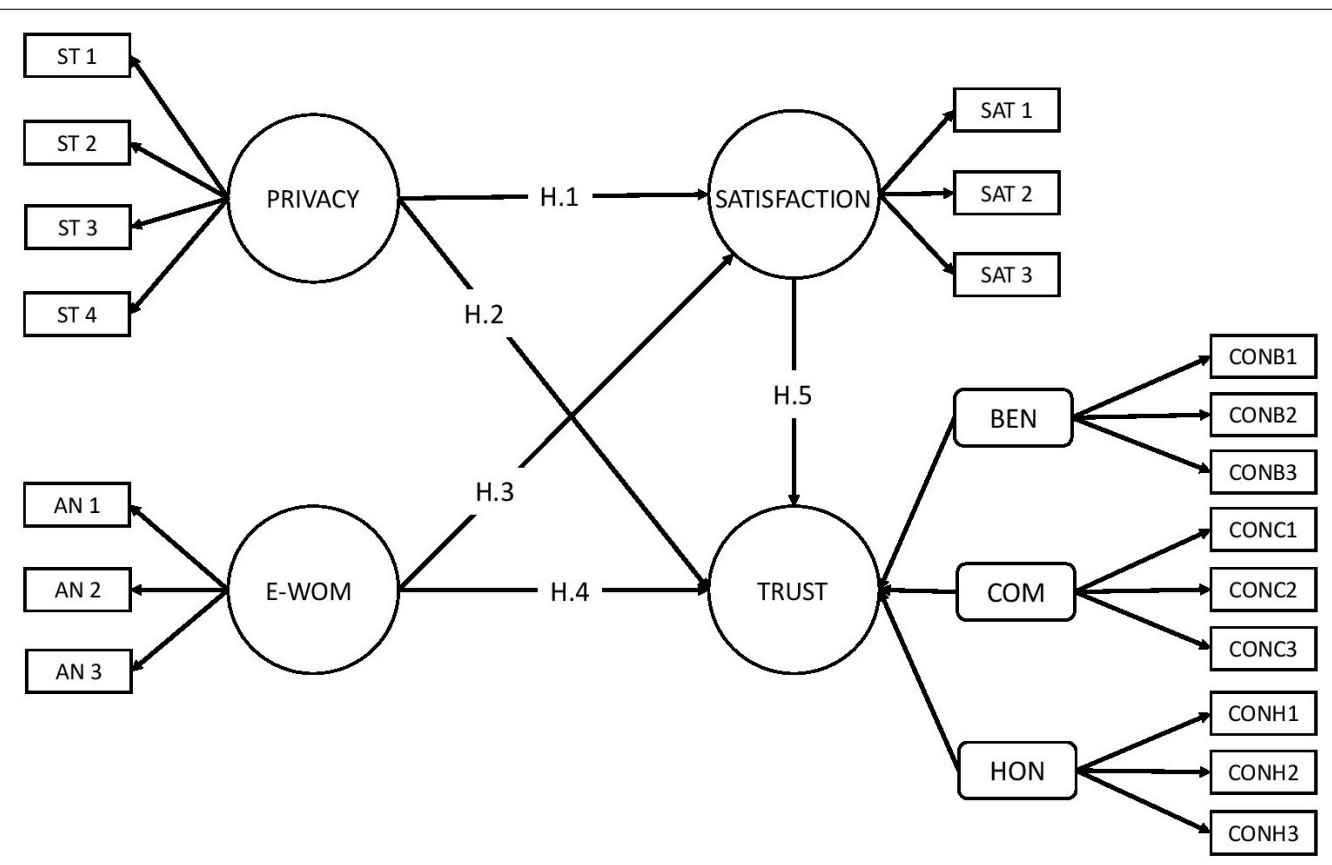

FIGURE 1 | Proposed research model. Source: own elaboration. 
employment status, age and education. For the second part of the questionnaire, a measurement scale was used, based on the bibliographical analysis carried out in this study. It analyses the variables privacy, E-WOM, satisfaction and trust. It should be noted that the trust variable is a multidimensional variable, so an analysis by dimensions (Benevolence, Honesty and Competence) had to be carried out. A total of 19 questions were asked to measure these variables.

The type of questions used were Likert scale questions from 0 to 6 ( 1 = "strongly disagree"; $6=$ "strongly agree"). The choice of these types of questions is motivated by the fact that they are able to analyze the degree of sensitivity of each user and are the most commonly used type of question in social science studies (Fernández-Fernández et al., 2021).

\section{Method of Data Analysis}

In order to carry out the validation of the measurement scale and the validation of the hypotheses put forward in the model, a structural equation analysis based on variances has been carried out (Liengaard et al., 2021). The PLS-SEM method through the SmartPLS software has been used to process the data and test the hypotheses (Del-Castillo-Feito et al., 2020).

This is a multivariate analysis method whose main purpose is the prediction of dependent variables by estimating robust models. This program allows to analyze and determine the estimation of the measurement model and structural model taking into account their dependent variables. It also allows for the calculation and quantification of the size of both indirect and direct effects that some of the variables in this model have on others (Cachón-Rodríguez et al., 2021). The method has the advantage of deciding whether or not to impose the direction of the hypotheses and is considered to be the most reliable and advisable according to Hair et al. (2019).

The composition of the proposed model, which includes reflective and formative variables, makes this technique and software optimal for the analysis proposed in the study (Martínez-Navalón et al., 2020).

\section{ANALYSIS OF THE RESULTS}

Before starting the analysis of the proposed model in this study, the structure to be developed for this analysis must be taken into account. The first thing to do is to validate the measurement scale in order to be able to carry out the analysis of the model. The validation of the measurement scale of this model is a twostep validation, due to the fact that there is a multidimensional variable (trust) in this model. In order to validate a model with a multidimensional variable, all the items that make up the dimensions must first be analyzed and then grouped together to form an item for each dimension. The first step to be carried out is called "validation of the measurement scale of the first order model" and the second step is called "validation of the measurement scale of the second order model" (Hair et al., 2019).

During the validation analysis of both the first and second order measurement scale, items that do not meet the requirements for the validation of the measurement scale will be eliminated, and then proceed with the measurement of the model (Gelashvili et al., 2021).

\section{Analysis of the Survey Population}

Before starting with the analysis of the measurement scale and the analysis of the model, the classificatory data analysis of the sample obtained from the questionnaires is carried out. This analysis shows the data collected in the first part of the questionnaire and shows the characteristics of the sample.

Gender, employment status and age are studied in this analysis. This helps to have knowledge of the sample obtained. This makes it possible to specify to which levels of the population or styles of the population the results obtained in this work can be applied. The sample consists of 390 questionnaires (400 collected and 390 valid) (Table 1).

The descriptive analysis visible in Table 1 shows that the composition of the sample is mostly female. The female gender occupies $56.92 \%$ of the individuals surveyed, compared to $43.07 \%$ of the male gender. With regard to the age composition of the sample, it can be seen that the majority of the sample is made up of individuals aged between 21 and 35, followed by individuals aged between 36 and 55. Marginally the third group of individuals surveyed are in the age range 56-65 years. Finally, with regard to the employment status of the individuals, it can be seen that the majority of the sample is made up of employees (47.43\%), followed by $34.41 \%$ of students.

\section{Measurement Model}

To carry out the analysis of the proposed model, a validation analysis of the measurement scales must be carried out, as specified above, in order to subsequently carry out the analysis of the proposed relationships (Nitzl et al., 2016). Firstly, and given that this is an analysis with multidimensional variables, we begin by validating the measurement scale of the first-order model and, once the dimensions of the trust variable have been validated, we proceed to the validation of the complete measurement scale, known as the second-order scale (Hair et al., 2018). In the first-order model we find that all items have a reflective

\begin{tabular}{lccc} 
TABLE 1 | Sample characteristics $(n=390)$ & & \\
\hline Classification variable & Variable & Frequency & Percentage \\
\hline Gender & Male & 167 & $42.82 \%$ \\
Age & Female & 223 & $57.18 \%$ \\
& $<20$ & 36 & $9.23 \%$ \\
& $21-35$ & 255 & $65.38 \%$ \\
Employment status & $36-55$ & 54 & $13.85 \%$ \\
& $56-65$ & 39 & $10.00 \%$ \\
& $>65$ & 6 & $1.54 \%$ \\
& Unemployed & 30 & $7.69 \%$ \\
& Self-employed & 24 & $6.15 \%$ \\
& Employed & 185 & $47.44 \%$ \\
& Student & 133 & $34.10 \%$ \\
& Retired & 18 & $4.62 \%$
\end{tabular}

Source: own elaboration. 
character, while in the second-order model we observe that the variables privacy, E-WOM and satisfaction have a reflective character and that the variable trust has a formative character (Martínez-Navalón et al., 2020).

When carrying out the validation of the measurement scale, different criteria are applied for the reflective and formative items. In the case of the reflective items, an analysis of individual reliability, composite reliability, convergent validity and discriminant validity is carried out. These analyses can be found in Tables 2, 3 of the paper. In the case of the formative variables, the collinearity of the indicators is assessed through the analysis of the variance inflation factor (VIF) and their weights (Rodríguez et al., 2019).

First, we proceed to the individual reliability analysis of the study. In this analysis, the item loadings $(\lambda)$ are analyzed. These charges according to the criterion of Carmines and Zeller (1979) should be above 0.707. In this study, all items of the proposed first-order model exceed this cut-off threshold. Secondly, the validation analysis of the composite reliability scale is carried out, where the Cronbach's alpha analysis is taken into account (Martínez-Navalón et al., 2019). The criterion used is that of Nunnally and Bernstein (1994) which sets an item validation cut-off at 0.7 . Here too, all of the items raised pass this cut-off, as they all exceed 0.7 . To analyze composite reliability, the Dijkstra-Henseler analysis (rho_A) is used, a more up-to-date criterion that is more robust in its analysis (Dijkstra and Henseler, 2015). Becoming the only real measure of reliability (Hair et al., 2019). The cut-off score is 0.7. In both composite reliability criteria all the items tested pass the analysis.

The convergent validation analysis uses the average variance extracted (AVE) in which we study how much of the variance of a variable is generated by its indicators (Martínez-Navalón et al., 2020). It is analyzed to ensure that the proposed indicators account for at least $50 \%$ of the variance of the underlying variable. The cut-off rate is 0.5 (Rodríguez et al., 2019). In this analysis, all of the items in this study exceed the cut-off threshold of 0.5 (Table 2).

Finally, for the validation of the measurement scale of the first-order variables, discriminant validity analysis is carried out. This study is carried out using Heterotrait-Monotrait analysis (HTMT). This criterion is the most current and allows the study to be more robust (Dijkstra and Henseler, 2015). It takes into account that the amount of variance of a variable captured from the indicators must be greater than the variance it shares with other variables (Ghasemy et al., 2021). Values in the study must be less than 0.90 (Henseler et al., 2015). Having carried out the analysis in the proposed model, the items SAT-3, CONH-1,

TABLE 2 | Measurement items first order.

\begin{tabular}{|c|c|c|c|c|c|c|}
\hline Constructs & Items & $\begin{array}{l}\text { Correlation } \\
\text { loading }\end{array}$ & CA & CR & rho_A & AVE \\
\hline \multirow[t]{2}{*}{ Satisfaction } & ST-1 I am satisfied with the reviews on TripAdvisor. & $0.919^{\star \star \star}$ & 0.805 & 0.911 & 0.807 & 0.672 \\
\hline & ST-2 TripAdvisor always meets my expectations. & $0.911^{\star \star \star}$ & & & & \\
\hline \multirow[t]{4}{*}{ Privacidad } & PRIV-1 TripAdvisor explains and respects the privacy policy. & $0.892^{\star \star \star}$ & 0.883 & 0.918 & 0.918 & 0.737 \\
\hline & $\begin{array}{l}\text { PRIV-2 I don't mind giving my details to TripAdvisor because they are } \\
\text { protected. }\end{array}$ & $0.802^{\star \star \star}$ & & & & \\
\hline & $\begin{array}{l}\text { PRIV-3 I have peace of mind when browsing TripAdvisor because I } \\
\text { know that my information is protected. }\end{array}$ & $0.923^{\star \star \star}$ & & & & \\
\hline & $\begin{array}{l}\text { PRIV-4 When I write my reviews on TripAdvisor it does not show } \\
\text { personal information. }\end{array}$ & $0,809^{\star \star \star}$ & & & & \\
\hline \multirow[t]{4}{*}{ E-WOM } & $\begin{array}{l}\text { EW-1 Before I travel I check the opinions of other tourists on } \\
\text { TripAdvisor. }\end{array}$ & $0.865^{\star \star \star}$ & 0.883 & 0.89 & 0.890 & 0.672 \\
\hline & $\begin{array}{l}\text { EW-2 TripAdvisor has enough references (hotels, restaurants, } \\
\text { monuments) with opinions of other tourists. }\end{array}$ & $0.818^{\star \star \star}$ & & & & \\
\hline & EW-3 TripAdvisor allows me to choose the best tourist destination. & $0.883^{\star \star \star}$ & & & & \\
\hline & EW-4 TripAdvisor reviews always get it right. & $0.700^{\star \star \star}$ & & & & \\
\hline \multirow[t]{3}{*}{ Trust honesty } & CONH-2 TripAdvisor is transparent about the reviews it stores. & $0.905^{\star \star \star}$ & 0.858 & 0.914 & 0.914 & 0.779 \\
\hline & CONH-3 TripAdvisor is ethically and transparently managed. & $0.882^{\star \star \star}$ & & & & \\
\hline & CONH-4 I can trust TripAdvisor. & $0.860^{\star \star \star}$ & & & & \\
\hline \multirow[t]{2}{*}{ Trust benevolence } & $\begin{array}{l}\text { CONB- } 2 \text { TripAdvisor develops actions taking into account that they will } \\
\text { have an impact on its users. }\end{array}$ & $0.874^{\star \star \star}$ & 0.700 & 0.863 & 0.863 & 0.758 \\
\hline & $\begin{array}{l}\text { CONB-3 TripAdvisor takes into account its stakeholders (users and } \\
\text { destinations, restaurants, hotels, etc., about which they give their } \\
\text { opinions) so as not to harm them. }\end{array}$ & $0.868^{\star \star \star}$ & & & & \\
\hline \multirow[t]{2}{*}{ Trust competence } & $\begin{array}{l}\text { CONC-2 TripAdvisor shows the necessary capacity to be able to carry } \\
\text { out its work. }\end{array}$ & $0.895^{\star \star \star}$ & 0.782 & 0.902 & 0.902 & 0.821 \\
\hline & CONC-3 TripAdvisor performs competently as a review site. & $0.917^{\star \star \star}$ & & & & \\
\hline
\end{tabular}

CA, Cronbach's alpha; CR, Composite reliability; rho_A, Dijkstra-Henseler indicator; AVE, Average Variance Extracted.

${ }^{* * *} p<0.001$.

Source: own elaboration. 
TABLE 3 | Measurement of the fist-order model (discriminant validity).

\begin{tabular}{|c|c|c|c|c|c|c|}
\hline \multicolumn{7}{|c|}{ Heterotrait-Monotrait Ratio (HTMT) } \\
\hline & E-WOM & Privacy & Satisfaction & Trust benevolence & Trust competence & Trust honesty \\
\hline \multicolumn{7}{|l|}{ E-WOM } \\
\hline Privacy & 0.078 & & & & & \\
\hline Satisfaction & 0.855 & 0.075 & & & & \\
\hline Trust-benevolence & 0.856 & 0.12 & 0.757 & & & \\
\hline Trust-competence & 0.869 & 0.082 & 0.873 & 0.864 & & \\
\hline Trust-honesty & 0.797 & 0.1 & 0.83 & 0.822 & 0.754 & \\
\hline
\end{tabular}

Source: own elaboration.

CONB-1, CONC-2 are eliminated as they do not comply with the proposed criteria (Table 3 ).

Once the validation of the measurement scale of the firstorder model has been completed, the validated items of the multidimensional variable (trust) are grouped together. The validation analysis of the measurement scale is carried out again, but in this case of the second-order model. In this second analysis, the reflective variables (privacy, E-WOM and satisfaction) meet all the criteria previously analyzed, and the scale for measuring these variables is considered to be validated. Subsequently, the validation of the formative variable (trust) is carried out, as the measurement scale of the formative variables is validated with different criteria. First, the weights are analyzed to see if they are significant (Gelashvili et al., 2021). All three items of the trust variable in the second order are significant. Once the weighting criterion has been overcome, the collinearity study of the items is carried out. This analysis is performed using the VIF (Hair et al., 2018). The chosen cut-off threshold is the one advocated by Hair et al. (2019) where it is advised that VIFs should be close to value 3, preferably with a lower value. Applying this criterion, the three items of the trust variable are retained (Table 4 ).

The measurement analysis is carried out, where it is analyzed whether the hypotheses are fulfilled or rejected.

\section{Structural Model Analysis}

In order to carry out the structural analysis of the model previously proposed, it is necessary to analyze whether there is multicollinearity between the antecedent variables and the endogenous variables. For this purpose, structural variance inflation is analyzed using the (VIF) criterion, where the structural model must have values less than 3 according to Hair et al. (2019). In this case, the structural model meets this criterion as there is no structural multicollinearity since all values are below 2. The goodness-of-fit index of the model must also be measured beforehand. For a model to be considered a good fit, the SRMR index must be less than 0.08 ( $\mathrm{Hu}$ and Bentler, 1998). The fit index of this model is 0.06 and therefore meets this criterion.

Once the previous analyses have been carried out, a bootstrapping analysis of 50,000 samples is applied, which allows us to see the algebraic sign, the magnitude and the significance of the hypotheses put forward. In the analysis of the algebraic sign, it can be seen that all the hypotheses have the same value as the hypothesis that has been put forward. The Student's $t$-test and significance analysis shows that hypotheses 1, 3, 4, and 5 meet the criteria for both analyses, while hypothesis 2 does not meet the criteria. Therefore, the hypothesis H.2 (Privacy $\rightarrow$ Trust) is rejected and H.1 (Privacy $\rightarrow$ Satisfaction), H.3 (E-WOM $\rightarrow$ Satisfaction), H.4 (E-WOM $\rightarrow$ Trust), H.5(Satisfaction $\rightarrow$ Trust) are accepted (Table 5).

Once the hypotheses have been accepted and rejected, the analysis of explained variance $\left(\mathrm{R}^{2}\right)$ and effect size $\left(\mathrm{F}^{2}\right)$ is carried out to measure the predictive relevance of the model (Aldás-Manzano, 2014; Hair et al., 2019). The $\mathrm{R}^{2}$ for trust and the $\mathrm{R}^{2}$ for satisfaction show positive values. In the case of trust it has high values according to Chin (1998) and in the case of satisfaction it has average values. This indicates that the predictor variables have a high predictive power. $\mathrm{F}^{2}$ shows how an exogenous variable contributes to explain another endogenous variable. The E-WOM variable exerts a large explanatory effect on the satisfaction and trust variables. In the case of the privacy variable, it has a low explanatory effect on satisfaction. Finally, we measure the predictive relevance of the model

TABLE 4 | Measurement of the second-order model.

\begin{tabular}{lccc}
\hline Constructs & Dimensions & Correlation (weights) & VIF \\
\hline Trust & Honesty & $0.454^{\star \star *}$ & 1.914 \\
& Benevolence & $0.162^{\star \star \star}$ & 1.956 \\
& Competence & $0.523^{\star \star \star}$ & 1.924 \\
\hline
\end{tabular}

VIF, Variance Inflation Factor.

${ }^{* * *} p<0.001$.

Source: own elaboration.

TABLE 5 | Comparison of hypotheses.

\begin{tabular}{lccc}
\hline & Path coeff $(\mathscr{B})$ & Statistics T ( $\mathscr{B} /$ STDEV) & $\mathbf{f}^{\mathbf{2}}$ \\
\hline H1. Privacy $\rightarrow$ Satisfaction & $0.1^{*}$ & 2.43 & 0.02 \\
H3. E-WOM $\rightarrow$ Satisfaction & $0.71^{\star \star \star}$ & 24.76 & 0.99 \\
H4. E-WOM $\rightarrow$ Trust & $0.47^{\star \star \star}$ & 10.65 & 0.37 \\
H5. Satisfaction $\rightarrow$ Trust & $0.441^{\star \star \star}$ & 9.482 & 0.33 \\
\hline
\end{tabular}

$R^{2}:$ Trust $=0.704 ;$ Satisfaction $=0.5$.

$R^{2}$ tight: Trust $=0.701 ;$ Satisfaction $=0.498$.

$Q^{2}$ : Trust $=0.511 Q^{2}$ : Satisfaction $=0.414$.

${ }^{*} p<0.05 ;{ }^{* *} p<0.01 ;{ }^{* * *} p<0.001$.

Source: own elaboration. 


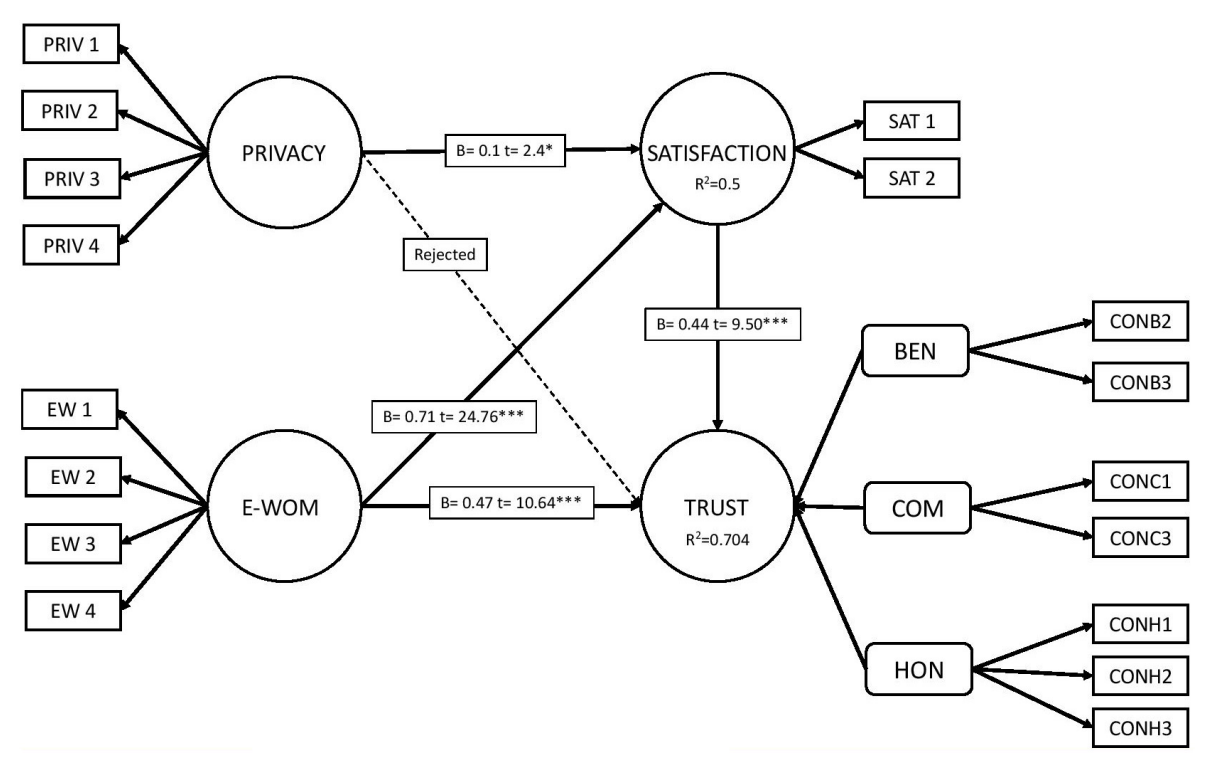

FIGURE 2 | Final model. Source: own elaboration. ${ }^{* * *} p<0.001$

by (Q2), obtaining a high predictive relevance (Geisser, 1975; Martínez-Navalón et al., 2019).

Table 5 and Figure 2 show the results obtained in the study.

\section{CONCLUSION}

TripAdvisor is one of the largest platforms for reviews in the tourism sector where users express their opinions about the services they receive. These opinions can have an impact on the decision of other users, therefore the impact of this platform for tourism and hospitality companies as well as for its users is very important. Therefore, the two main objectives of this study were to analyze if the privacy of users when using TripAdvisor, has an impact on their satisfaction and trust on the platform and examine the relationship between E-WOM and users trust and satisfaction when using TripAdvisor.

The first block of analysis studied the relationship between TripAdvisor users' perceptions of safety and the trust and satisfaction generated. The results have shown that user privacy on the TripAdvisor platform has a direct and positive relationship with user satisfaction. Therefore $\mathrm{H} 1$ is accepted. This result is an important contribution to the academic literature since several studies had denied positive relationship between these two variables (Cheng and Jiang, 2020) and others had confirmed the non-existence of this relationship (Kim et al., 2012). With regard to relation between users privacy and trust results have shown that there is no relationship between these two variables. On this basis $\mathrm{H} 2$ was rejected. This means that users' privacy does not condition their trust on the platform.

The second block analyzed the relationship between E-WOM and TripAdvisor user satisfaction and trust. The results have shown that E-WOM has a direct and positive relationship with the satisfaction and trust of the platform's users. On this basis the
$\mathrm{H} 3$ and H4 have been accepted. This result is in line with previous researches (Bhandari and Rodgers, 2017; Tandon et al., 2020) and contributes to the academic literature for one of the world's largest platform of opinion. Finally, the relationship between the variables satisfaction and trust of users of the TripAdvisor platform has been analyzed. The result showed a direct and positive relationship between these two variables. This means that if a user of this platform is satisfied with the service, this generates a higher degree of trust toward the platform. Therefore the H5 has been validated. The relationship between satisfaction and trust has been identified by other authors (Lai, 2014; Martínez-Navalón et al., 2019) but in the tourism sector, not specifically for the TripAdvisor platform.

Taking into account the results of the study, this research has theoretical and practical implications. In case of theoretical implications the importance of the study in the academic literature can be highlighted. The literature on some of the points analyzed in this research has not been uniform and clear. Therefore, this study contributes to the academic literature on the variables analyzed (privacy, E-WOM, satisfaction, trust). In case of practical implications we can highlight the importance of E-WOM for user satisfaction and trust, therefore the managers of TripAdvisor or other similar digital platforms should take into account the importance of the positive and direct relationship between E-WOM and satisfaction and trust of the users.

The present research has several limitations. First, only one review platform is analyzed, it would be interesting to compare whether the result would be the same for users of other Apps such as Google maps or Booking. Second, another methodology could be used to reinforce the results obtained. Thirdly, the sample could be increased and differentiated by gender as many recent studies point to the importance of this variable. Taking into account the limitations outlined in this study, future research lines could focus on overcoming these gaps. 


\section{DATA AVAILABILITY STATEMENT}

The raw data supporting the conclusions of this article will be made available by the authors, without undue reservation.

\section{REFERENCES}

Aakash, A., and Aggarwal, A. G. (2019). "Role of EWOM, product satisfaction, and website quality on customer repurchase intention," in Strategy and Superior Performance of Micro and Small Businesses in Volatile Economies, eds J. Carvalho and E. Sabino (Hershey, PA: IGI Global), 144-168. doi: 10.4018/9781-5225-7888-8.ch010

Agudo-Peregrina, Á. F., Pascual-Miguel, F. J., and Chaparro-Peláez, J. (2014). It's never the same: the role of homogeneity in online services. Serv. Bus. 8, 453-464. doi: 10.1007/s11628-014-0249-7

Aïmeur, E., Lawani, O., and Dalkir, K. (2016). When changing the look of privacy policies affects user trust: an experimental study. Comp. Hum. Behav. 58, 368-379. doi: 10.1016/j.chb.2015.11.014

Al-Khalaf, E., and Choe, P. (2020). Increasing customer trust towards mobile commerce in a multicultural society: a case of Qatar. J. Internet Commer. 19, 32-61. doi: 10.1080/15332861.2019.1695179

Aldás-Manzano, M. J. (2014). "Confirmatory tetrad analysis as a tool to decide between the formative/reflective nature of constructs in marketing and management research," in Routledge Companion to the Future of Marketing, eds A. K. Moutinho, L. Bigné, and E. Manrai (Milton Park: Routledge), 348-378.

Alonso, M. (2016). Opinión pública y web 2.0. Las redes digitalizan el barómetro político en España. Rev. Mex. Opin. Pública 21, 95-113.

Alsini, I. (2017). Investigating effects of perceived service quality on overall service quality and customer satisfaction: case of Saudi Airlines. J. Spatial Organ. Dyn. 5, 463-470.

Apolo, D. E., Altamirano, V., and Vascónez, V. E. (2015). Usuarios, clientes y consumidores digitales: consideraciones para su abordaje desde el marketing y la comunicación corporativa. Redmarka 14, 3-19. doi: 10.17979/redma.2015. 01.014 .4879

Aurifeille, J. M., Medlin, C., and Tisdell, C. A. (2009). Trust, Globalisation and Market Expansion. Hauppauge NY: Nova Science Publishers.

Balagué, C., Martin-Fuentes, E., and Gómez, M. J. (2016). Fiabilidad de las críticas hoteleras autenticadas y no autenticadas: El caso de TripAdvisor y Booking. com. Cuad. Turismo 38, 67-86. doi: 10.6018/turismo.38.271351

Beigi, G., and Liu, H. (2018). Privacy in social media: identification, mitigation and applications. arxiv [Preprint] 9, arXiv:1808.02191

Belleflamme, P., and Peitz, M. (2018). La sala de máquinas de las plataformas digitales: opiniones, evaluaciones y recomendaciones. Papeles Econ. Española 157, 42-67.

Bhandari, M., and Rodgers, S. (2017). What does the brand say? Effects of brand feedback to negative eWOM on brand trust and purchase intentions. Int. J. Advert. 37, 125-141. doi: 10.1080/02650487.2017.1349030

Bigné, E., Küster, I., and Hernández, A. (2013). The social network sites and the brands. Influence of eC2C exchange of experience on brand users' attitudes. Rev. Española Invest. En Market. 17, 7-27.

Bilgihan, A., and Bujisic, M. (2015). The effect of website features in online relationship marketing: a case of online hotel booking. Electron. Commer. Res. Appl. 14, 222-232. doi: 10.1016/j.elerap.2014.09.001

Boukherouk, M., -dali, R., and Dbibirha, Y. (eds) (2020). "Sharing tourism and its impact on hospitality management in essaouira: analysis of the evolution of booking. com and airbnb," in Cultural and Tourism Innovation in the Digital Era, eds V. Katsoni and T. Spyriadis (Cham: Springer), 145-159. doi: 10.1007/ 978-3-030-36342-0_12

Buhalis, D., and Law, R. (2008). Progress in information technology and tourism management: 20 years on and 10 years after the Internet-The state of tourism research. Tour. Manage. 29, 609-623. doi: 10.1016/j.tourman.2008. 01.005

Cachón-Rodríguez, G., Blanco-González, A., Prado-Román, C., and Diez-Martin, F. (2021). Sustainability actions, employee loyalty, and the awareness: the mediating effect of organization legitimacy. Manage. Decis. Econ. doi: 10.1002/ mde. 3340

\section{AUTHOR CONTRIBUTIONS}

All authors listed have made a substantial, direct and intellectual contribution to the work, and approved it for publication.

Carmines, E., and Zeller, R. (1979). Reliability and Validity Assessment. Thousand Oaks CA: Sage.

Chen, M., Sinha, A., Hu, K., and Shah, M. I. (2021). Impact of technological innovation on energy efficiency in industry 4.0 era: moderation of shadow economy in sustainable development. Technol. Forecast. Soc. Change 164:120521. doi: 10.1016/j.techfore.2020.120521

Cheng, C., Luo, Y., and Yu, C. (2020). Dynamic mechanism of social bots interfering with public opinion in network. Physica A 551:124163. doi: 10.1016/ j.physa.2020.124163

Cheng, Y., and Jiang, H. (2020). How do AI-driven chatbots impact user experience? Examining gratifications, perceived privacy risk, satisfaction, loyalty, and continued use. J. Broadcast. Electron. Media 64, 592-614. doi: 10.1080/08838151.2020.1834296

Chin, W. W. (1998). "The partial least squares approach to structural equation modeling," in Modern Methods for Business Research, ed. G. A. Marcoulides (Mahwah, NJ: Lawrence Erlbaum Associates), 295-336.

Chumpitaz, R., and Paparoidamis, N. G. (2007). Service quality, relationship satisfaction, trust, commitment and business-to-business loyalty. Eur. J. Market. 41, 836-867. doi: 10.1108/03090560710752429

Chung, K. C., Chen, C. H., Tsai, H. H., and Chuang, Y. H. (2021). Social media privacy management strategies: a SEM analysis of user privacy behaviors. Comp. Commun. 174, 22-130. doi: 10.1016/j.comcom.2021.04.012

European Commission (2016). Regulation (EU) 2016/679 of 27 April 2016 on the Protection Of Natural Persons With Regard to the Processing of Personal Data and on the Free Movement of Such Data, and Repealing Directive 95/46/EC. Brussels: European Commission.

Crosby, L. A., Evans, K. R., and Cowles, D. (1990). Relationship quality in services selling: an interpersonal influence perspective. J. Market. 54, 68-81. doi: 10. $1177 / 002224299005400306$

Curry, S. (2021). Achieving GDPR compliance post-Privacy Shield. Comp. Fraud Secur. 2, 6-8. doi: 10.1016/S1361-3723(21)00017-8

Del-Castillo-Feito, C., Cachón-Rodríguez, G., and Paz-Gil, I. (2020). ). Political Disaffection, Sociodemographic, and Psychographic Variables as State Legitimacy Determinants in the European Union. Thousand Oaks CA: American Behavioral Scientist, Del-Castil.

Dijkstra, T. K., and Henseler, J. (2015). Consistent partial least squares path modeling. MIS Q. 39, 297-316.

Duarte, P., e Silva, S. C., and Ferreira, M. B. (2018). How convenient is it? Delivering online shopping convenience to enhance customer satisfaction and encourage e-WOM. J. Retailing Consum. Serv. 44, 161-169. doi: 10.1016/j. jretconser.2018.06.007

Dwyer, F. R., Schurr, P. H., and Oh, S. (1987). Developing buyer-seller relationships. J. Market. 51, 11-27. doi: 10.1177/002224298705100202

Eklof, J., Podkorytova, O., and Malova, A. (2020). Linking customer satisfaction with financial performance: an empirical study of Scandinavian banks. Total Qual. Manage. Bus. Excell.31, 1684-1702. doi: 10.1080/14783363.2018.1504621

El-Adly, M. I. (2019). Modelling the relationship between hotel perceived value, customer satisfaction, and customer loyalty. J. Retailing Consum. Serv. 50, 322-332. doi: 10.1016/j.jretconser.2018.07.007

Fainmesser, I. P., Galeotti, A., and Momot, R. (2019). "Digital privacy," in Paper Presented at HEC Paris Research Paper No., MOSI, 1351. Available online at: https://papers.ssrn.com/sol3/papers.cfm?abstract_id=3459274

Fernández-Fernández, M., Martínez-Navalón, J. G., and Gelashvili, V. (2021). Sustainability and online classes at the university in the times of COVID-19: has it served us as a starting point for a new kind of teaching? Rev. Espacios 42, $127-144$.

Fili, M., and Križaj, D. (2017). Electronic word of mouth and its credibility in tourism: the case of tripadvisor. Acad. Turistica Tour. Innov. J. 9, 107-111.

Funk, E., Riddell, J., Ankel, F., and Cabrera, D. (2018). Blockchain technology: a data framework to improve validity, trust, and accountability of information exchange in health professions education. Acad. Med. 93, 1719-1794. 
Geisser, S. (1975). The predictive sample reuse method with applications. J. Am. Stat. Assoc. 70, 320-328. doi: 10.1080/01621459.1975.10479865

Gelashvili, V., Martínez-Navalón, J. G., and Enríquez, G. H. (2021). How stress and anxiety when using mobile restaurant reservation Apps influence users' satisfaction and trust. J. Indian Bus. Res. 13, 395-412. doi: 10.1108/JIBR-082020-0276

Ghasemy, M., Muhammad, F., Jamali, J., and Roldán, J. L. (2021). Satisfaction and performance of the international faculty: to what extent emotional reactions and conflict matter? SAGE Open 11, 1-15. doi: 10.1177/21582440211030598

Gil, Á. R., Barandalla, I. C. J., and Idoeta, C. M. (2017). Reputación corporativa online en la hotelería: el caso TripAdvisor. ESIC Market 158, 579-608. doi: 10.7200/esicm.158.0483.4

Goldenberg, J., Oestreicher-Singer, G., and Reichman, S. (2012). The quest for content: how user-generated links can facilitate online exploration. J. Market. Res. 49, 452-468. doi: 10.1509/jmr.11.0091

Goyette, I., Ricard, L., Bergeron, J., and Marticotte, F. (2012). E-WOM Scale: wordof-mouth measurement scale for e-services context. Can. J. Adm. Sci. 27, 5-23. doi: $10.1002 /$ cjas. 129

Guping, C., Cherian, J., Sial, M. S., Mentel, G., Wan, P., Álvarez-Otero, S., et al. (2021). The relationship between csr communication on social media, purchase intention, and e-wom in the banking sector of an emerging economy. J. Theor. Appl. Electron. Commer. Res. 16, 1025-1041. doi: 10.3390/jtaer16040058

Hair, J. F., Risher, J. J., Sarstedt, M., and Ringle, C. M. (2019). When to use and how to report the results of PLS-SEM. Eur. Bus. Rev. 31, 2-24. doi: 10.1108/ebr-112018-0203

Hair, J. F., Sarstedt, M., Ringle, C. M., and Gudergan, S. P. (2018). Advance Issues in Partial Least Squares Structural Equation Modeling (Los Angele). Los Angele CA: Sage.

Hennig-Thurau, T., Gwinner, K. P., Walsh, G., and Gremler, D. (2004). Electronic word-of-mouth via consumer-opinion platforms: what motivates consumers to articulate themselves on the internet? J. Interactive Market. 18, 38-52. doi: 10.1002/dir.10073

Henning-Thurau, T., Langer, M., and Hansen, U. (2001). Modelling and managing student loyalty: an approach based on the concept of relationship quality. J. Serv. Res. 3, 331-344. doi: 10.1177/109467050134006

Henseler, J., Ringle, C. M., and Sarstedt, M. (2015). A new criterion for assessing discriminant validity in variance-based structural equation modeling. J. Acad. Market. Sci. 43, 115-135. doi: 10.1007/s11747-014-0403-8

Heyes, A., and Kapur, S. (2012). Angry customers, e-word-of-mouth and incentives for quality provision. J. Econ. Behav. Organ. 84, 813-828. doi: 10.1016/j.jebo. 2012.10.002

Hossain, M. S., Hasan, R., Kabir, S. B., Mahbub, N., and Zayed, N. M. (2019). Customer participation, value, satisfaction, trust and loyalty: an interactive and collaborative strategic action. Acad. Strategic Manage. J. 18, 1-17.

Hu, L. T., and Bentler, P. M. (1998). Fit indices in covariance structure modeling: sensitivity to underparameterized model misspecification. Psychol. Methods 3:424. doi: 10.1037/1082-989x.3.4.424

Ismagilova, E., Slade, E., Rana, N. P., and Dwivedi, Y. K. (2019). The effect of characteristics of source credibility on consumer behaviour: a meta-analysis. J. Retailing Consum. Serv. 53:101736. doi: 10.1016/j.jretconser.2019.01.005

Jani, D., and Han, H. (2011). Investigating the key factors affecting behavioral intentions: evidence from a full-service restaurant setting. Int. J. Contemp. Hosp. Manage. 23, 1000-1018. doi: 10.1108/09596111111167579

Jiménez-Castillo, D., and Sánchez-Fernández, R. (2019). The role of digital influencers in brand recommendation: examining their impact on engagement, expected value and purchase intention. Int. J. Inform. Manage. 49, 366-376. doi: 10.1016/j.ijinfomgt.2019.07.009

Kanje, P., Charles, G., Tumsifu, E., Mossberg, L., and Andersson, T. (2020). Customer engagement and eWOM in tourism. J. Hosp. Tour. Insights 3, 273289. doi: 10.1108/JHTI-04-2019-0074

Kayes, I., and Iamnitchi, A. (2017). Privacy and security in online social networks: a survey. Online So. Netw. Media 3, 1-21. doi: 10.1016/j.osnem.2017.09.001

Kim, Y. J., Kim, J. Y., and Han, J. M. (2012). The structural relationships among user citizenship behavior, aberrant user behavior, social connectedness, privacy concern, and user satisfaction. J. Korea Acad. Indust. Coop. Soc. 13, 4994-5004. doi: 10.5762/KAIS.2012.13.11.4994

Komiak, S. X., and Benbasat, I. (2004). Understanding customer trust in agent-mediated electronic commerce, web-mediated electronic commerce, and traditional commerce. Inform. Technol. Manage. 5, 181-207. doi: 10.1023/b: item.0000008081.55563.d4

Krishna, A., and Kim, S. (2020). Exploring customers' situational and word-ofmouth motivations in corporate misconduct. Public Relat. Rev. 46:101892. doi: 10.1016/j.pubrev.2020.101892

Ladhari, R., and Michaud, M. (2015). EWOM effects on hotel booking intentions, attitudes, trust, and website perceptions. J. Hosp. Manage. 46, 36-45. doi: 10. 1016/j.ijhm.2015.01.010

Lai, I. K. W. (2014). The role of service quality, perceived value, and relationship quality in enhancing customer loyalty in the travel agency sector. J. Travel Tour. Market. 31, 417-442. doi: 10.1080/10548408.2014.883346

Lassala, C., Ruiz, C., and Sanz, S. (2010). Implicaciones de la satisfacción, confianza y lealtad en el uso de los servicios bancarios online. Un análisis aplicado al mercado español. Rev. Eur. Dirección Econ. Empresa 19, 27-46.

Lax, G., Russo, A., and Fascì, L. S. (2021). Information sciences. Inform. Sci. 557, 220-235. doi: 10.1016/j.ins.2021.01.004

Leninkumar, V. (2017). The relationship between customer satisfaction and customer trust on customer loyalty. Int. J. Acad. Res. Bus. Soc. Sci. 7, 450-465.

Li, X., Wu, C., and Mai, F. (2019). The effect of online reviews on product sales: a joint sentiment-topic analysis. Effect Online Rev. Prod. Sales 56, 172-184. doi: $10.1016 /$ j.im.2018.04.007

Liang, L. J., Choi, H. C., and Joppe, M. (2018). Exploring the relationship between satisfaction, trust and switching intention, repurchase intention in the context of Airbnb. Int. J. Hosp. Manage. 69, 41-48. doi: 10.1016/j.ijhm.2017.10.015

Liengaard, B. D., Sharma, P. N., Hult, G. T. M., Jensen, M. B., Sarstedt, M., Hair, J. F., et al. (2021). Prediction: coveted, yet forsaken? Introducing a crossvalidated predictive ability test in partial least squares path modeling. Decis. Sci. 52, 362-392. doi: 10.1111/deci.12445

López, M., and Sicilia, M. (2014). Determinants of E-WOM influence: the role of consumers' internet experience. J. Theor. Appl. Electron. Commer. Res. 9, 28-43.

Mariottini, L., and Toribio, M. I. H. (2017). La narración de experiencias en TripAdvisor. Rilce 33, 302-330. doi: 10.15581/008.33.1.302-30

Martínez-Navalón, J. G., Gelashvili, V., and Debasa, F. (2019). The impact of restaurant social media on environmental sustainability: an empirical study. Sustainability 11:6105. doi: 10.3390/su11216105

Martínez-Navalón, J. G., Gelashvili, V., and Saura, J. R. (2020). The impact of environmental social media publications on user satisfaction with and trust in tourism businesses. Environ. Res. Public Health 17:5417. doi: 10.3390/ ijerph 17155417

McKnight, D. H., and Chervany, N. L. (2001). What trust means in e-commerce customer relationships: an interdisciplinary conceptual typology. Int. J. Electron. Commer. 6, 35-59. doi: 10.1080/10864415.2001.11044235

Miguéns, J., Baggio, R., and Costa, C. (2008). Social media and tourism destinations: tripadvisor case study. Adv. Tour. Res. 26, 1-6.

Mishra, Y., and Singh, A. (2019). Influence of customer generated e-WoM on tourist satisfaction: an empirical investigation. Manage. Today 9, 7-15. doi: 10.11127/gmt.2019.03.02

Munuera, G. P. (2017). Privacidad y seguridad. Derechos de los ciudadanos en el siglo de las nuevas tecnologias en España. Rev. Eur. Droit Soc. 4, 17-30.

Mutimukwe, C., Kolkowska, E., and Grönlund, § (2020). Information privacy in e-service: Effect of organizational privacy assurances on individual privacy concerns, perceptions, trust and self-disclosure behavior. Gov. Inform. Q. 37:101413. doi: 10.1016/j.giq.2019.101413

Nieto-García, M., Muñoz-Gallego, P. A., and González-Benito, Ó (2017). Tourists' willingness to pay for an accommodation: the effect of eWOM and internal reference price. Int. J. Hosp. Manage. 62, 67-77. doi: 10.1016/j.ijhm.2016.12.006

Nitzl, C., Roldán, J. L., and Cepeda, G. (2016). Mediation analysis in partial least squares path modeling: helping researchers discuss more sophisticated models. Indust. Manage. Data Syst. 116, 1849-1864. doi: 10.1108/imds-07-20 15-0302

Nunnally, J. C., and Bernstein, I. H. (1994). Psychometric Theory, 3edn Edn. New York NY: MCGraw-Hil.

Nuseir, M. T. (2019). The impact of electronic word of mouth (e-WOM) on the online purchase intention of consumers in the Islamic countries-a case of (UAE). J. Islamic Market. 10, 759-767. doi: 10.1108/JIMA-03-20180059

O'connor, P. (2008). User-generated content and travel: a case study on Tripadvisor. Com. Enter 2008, 47-58. doi: 10.1007/978-3-211-77280-5_5 
Orabi, M., Mouheb, D., Al Aghbari, Z., and Kamel, I. (2020). Detection of bots in social media: a systematic review. Inform. Proc. Manage. 57:102250. doi: 10.1016/j.ipm.2020.102250

Otto, A. S., Szymanski, D. M., and Varadarajan, R. (2020). Customer satisfaction and firm performance: insights from over a quarter century of empirical research. 48(3), 543-564. J. . Market. Sci. 48, 543-564. doi: 10.1007/s11747019-00657-7

Pérez-Aranda, J., Carbonero, R. N., and Vallespín, M. (2017). Análisis del sector hotelero en la relación "compromiso con las plataformas de valoración y resultados.”Int. J. Inform. Syst. Tour. (IJIST) 2, 7-16.

Pilton, C., Faily, S., and Henriksen-Bulmer, J. (2021). Evaluating privacydetermining user privacy expectations on the web. Comp. Secur. 105:102241. doi: 10.1016/j.cose.2021.102241

Politou, E., Michota, A., Alepis, E., Pocs, M., and Patsakis, C. (2018). Backups and the right to be forgotten in the GDPR: an uneasy relationship. Comp. Law Secur. Rev. 34, 1247-1257. doi: 10.1016/j.clsr.2018.08.006

Reimer, T., and Benkenstein, M. (2016). When good WOM hurts and bad WOM gains: the effect of untrustworthy online reviews. J. Bus. Res. 69, 5993-6001. doi: 10.1016/j.jbusres.2016.05.014

Reyes-Menendez, A., Saura, J. R., and Martínez-Navalón, J. G. (2019). The impact of e-WOM on hotels management reputation: exploring tripadvisor review credibility with the ELM model. IEEE Access 7, 68868-68877. doi: 10.1109/ access.2019.2919030

Rialti, R., Zollo, L., Pellegrini, M. M., and Ciappei, C. (2017). Exploring the antecedents of brand loyalty and electronic word of mouth in social-mediabased brand communities: do gender differences matter? J. Global Market. 30, 147-160. doi: 10.1080/08911762.2017.1306899

Ribeiro-Navarrete, S., Saura, J. R., and Palacios-Marqués, D. (2021). Towards a new era of mass data collection: assessing pandemic surveillance technologies to preserve user privacy. Technol. Forecast. Soc. Change 167:120681. doi: 10.1016/ j.techfore.2021.120681

Rodríguez, G. C., Román, C. P., and Zúñiga-Vicente, J. Á (2019). The relationship between identification and loyalty in a public university: are there differences between (the perceptions) professors and graduates? Eur. Res. Manage. Bus. Econ. 25, 122-128. doi: 10.1016/j.iedeen.2019.04.005

Sa'ait, N., Kanyan, A., and Nazrin, M. F. (2016). The effect of e-WOM on customer purchase intention. Int. Acad. Res. J. Soc. Sci. 2, 73-80.

Sánchez, J. A., and Arroyo-Cañada, F. J. (2016). Diferencias de la adopción del comercio electrónico entre países. Suma Negocios 7, 141-150. doi: 10.1016/j. sumneg.2016.02.008

Sarathy, R., and Robertson, C. J. (2003). Strategic and ethical considerations in managing digital privacy. J. Bus. Ethics 46, 111-126. doi: 10.1023/A: 1025001627419

Sarikakis, K., and Winter, L. (2017). Social media users' legal consciousness about privacy. Soc. Media Soc. 3:2056305117695325. doi: 10.1177/2056305117695325

Saura, J. R. (2020). Using data sciences in digital marketing: framework, methods, and performance metrics. J. Innov. Knowledge 6, 92-102. doi: 10.1016/j.jik.2020. 08.001

Saura, J. R., Palacios-Marqués, D., and Iturricha-Fernández, A. (2021a). Ethical design in social media: assessing the main performance measurements of user online behavior modification. J. Bus. Res. 129, 271-281. doi: 10.1016/j.jbusres. 2021.03.001

Saura, J. R., Ribeiro-Soriano, D., and Palacios-Marques, D. (2021b). Evaluating security and privacy issues of social networks based information systems in Industry 4.0. Enterprise Inform. Syst. 16, 1-17. doi: 10.1080/17517575.2021. 1913765

Saura, J. R., Ribeiro-Soriano, D., and Palacios-Marqués, D. (2021c). From usergenerated data to data-driven innovation: a research agenda to understand user privacy in digital markets. Int. J. Inform. Manage. 60:102331. doi: 10.1016/j. ijinfomgt.2021.102331

Serra-Cantallops, A., Cardona, J. R., and Salvi, F. (2020). Antecedents of positive eWOM in hotels. Exploring the relative role of satisfaction, quality and positive emotional experiences. Int. J. Contemp. Hosp. Manage. 32, 3457-3477. doi: 10.1108/IJCHM-02-2020-0113

Shamdasani, P. N., and Balakrishnan, A. A. (2000). Determinants of relationship quality and loyalty in personalised services. Asia Pacific J. Manage. 17, 399-422. doi: 10.1023/A:1015834214570

Sturm, U., Gold, M., Luna, S., Schade, S., Ceccaroni, L., Kyba, C., et al. (2018). Defining principles for mobile apps and platforms development in citizen science. Res. Ideas Outcomes 4:e23394. doi: 10.3897/rio.4.e23394
Swan, J. E., Trawick, I. F., and Silva, D. W. (1985). How industrial salespeople gain customer trust. Indust. Market. Manage. 14, 203-211. doi: 10.1016/00198501(85)90039-2

Tamburri, D. A. (2020). Design principles for the General Data Protection Regulation (GDPR): a formal concept analysis and its evaluation. Inform. Syst. 91:101469. doi: 10.1016/j.is.2019.101469

Tandon, A., Aakash, A., and Aggarwal, A. G. (2020). Impact of EWOM, website quality, and product satisfaction on customer satisfaction and repurchase intention: moderating role of shipping and handling. Int. J. Syst. Assur. Eng. Manage. 11, 1-8. doi: 10.1007/s13198-020-00954-3

Tao, K., and Edmunds, P. (2018). Mobile APPs and global markets. Theor. Econo. Lett. 8:1510. doi: 10.4236/tel.2018.88097

Thamrin, G., Bernarto, I., and Kawata, Y. (2020). The influence of trust, satisfaction, value, and brand image on loyalty. BISMA (Bisnis Dan Manajemen) 12, 168-185. doi: 10.26740/bisma.v12n2.p168-185

Tjhin, V. U., and Aini, S. R. N. (2019). "Effect of E-WOM and social media usage on purchase decision in clothing industry," in Proccedings of the 2019 th International Conference on E-business and Mobile Commerce, (New York NY), 30-34. doi: 10.1145/3332324.3332333

Tran, G. A., and Strutton, D. (2020). Comparing email and SNS users: investigating e-servicescape, customer reviews, trust, loyalty and E-WOM. J. Retailing Consum. Serv. 53:101782. doi: 10.1016/j.jretconser.2019.03.009

Trepte, S. (2020). The social media privacy model: privacy and communication in the light of social media affordances. Commun. Theory qtz035. doi: 10.1093/ct/ qtz035

Valdivia, A., Luzón, M. V., and Herrera, F. (2017). Sentiment analysis in tripadvisor. IEEE Intell. Syst. 32, 72-77. doi: 10.1109/MIS.2017.3121555

Voloch, N., Gal-Oz, N., and Gudes, E. (2021). A trust based privacy providing model for online social networks. Online Soc. Netw. Media 24:100138. doi: 10.1016/j.osnem.2021.100138

Wang, J. J., Wang, L. Y., and Wang, M. M. (2018). Understanding the effects of eWOM social ties on purchase intentions: a moderated mediation investigation. Electron. Commer. Res. Appl. 28, 54-62. doi: 10.1016/j.elerap.2018. 01.011

Wu, Y., Liang, Z., and Liu, L. (2013). "Design and implementation of tourism information system based on Google Maps API," in Proceedings of the 2013 21st International Conference on Geoinformatics, (Kaifeng), 1-4. doi: 10.1109/ Geoinformatics.2013.6626139

Wu, Z., Shen, S., Zhou, H., Li, H., Lu, C., and Zou, D. (2021). An effective approach for the protection of user commodity viewing privacy in e-commerce website. Knowledge Based Syst. 220:106952. doi: 10.1016/j.knosys.2021.106952

Yoo, K. H., Sigala, M., and Gretzel, U. (2016). "Exploring tripadvisor," in Open Tourism, eds R. Egger, I. Gula, and D. Walcher (Berlin: Springer), 239-255. doi: 10.1007/978-3-642-54089-9_17

Zhang, D., Mahmood, A., Ariza-Montes, A., Vega-Muñoz, A., Ahmad, N., Han, H., et al. (2021). Exploring the impact of corporate social responsibility communication through social media on banking customer e-wom and loyalty in times of crisis. Int. J. Environ. Res. Public Health 18:4739. doi: 10.3390/ ijerph18094739

Zhang, J., and Bloemer, J. M. (2008). The impact of value congruence on consumer-service brand relationships. J. Serv. Res. 11, 161-178. doi: 10.1177/ 1094670508322561

Conflict of Interest: The authors declare that the research was conducted in the absence of any commercial or financial relationships that could be construed as a potential conflict of interest.

Publisher's Note: All claims expressed in this article are solely those of the authors and do not necessarily represent those of their affiliated organizations, or those of the publisher, the editors and the reviewers. Any product that may be evaluated in this article, or claim that may be made by its manufacturer, is not guaranteed or endorsed by the publisher.

Copyright (C) 2021 Martínez-Navalón, Gelashvili and Gómez-Ortega. This is an openaccess article distributed under the terms of the Creative Commons Attribution License (CC BY). The use, distribution or reproduction in other forums is permitted, provided the original author(s) and the copyright owner(s) are credited and that the original publication in this journal is cited, in accordance with accepted academic practice. No use, distribution or reproduction is permitted which does not comply with these terms. 